\title{
EFEKTIVITAS HUKUM DALAM PELAKSANAAN PROGRAM DANA DESA (DD) DAN ALOKASI DANA DESA (ADD) UNTUK WILAYAH TERPENCIL (Studi Kasus di Desa Sabaru, Kecamatan Liukang Kalmas, Kabupaten Pangkep)
}

\author{
The Legal Effectiveness in the Implementation of Village Funds (VF) Programs and Village \\ Funds Allocation (VFA) for Remote Areas \\ (Case Study in Sabaru Village, Liukang Kalmas District, Pangkep Regency) \\ Rusnandi Nur ${ }^{1}$, Marwan Mas ${ }^{2}$, Abdul Salam Siku ${ }^{3}$ \\ ${ }^{1,2,3}$ Program Studi Ilmu Hukum Program Pascasarjana Universitas Bosowa \\ Email: rusnandinur@yahoo.co.id
}

Diterima: 08 Agustus 2019/Disetujui: 09 Desember 2019

\begin{abstract}
ABSTRAK
Tujuan penelitian ini adalah untuk mengetahui dan menganalisis faktor-faktor apa saja yang mempengaruhi efektifitas hukum terhadap pelaksanaan program Dana Desa (DD) dan Alokasi Dana Desa (ADD) untuk wilayah terpencil, khususnya di Desa Sabaru Kecamatan Liukang Kalmas, Kabupaten Pangkep. Penelitian ini menggunakan jenis penelitian kualitatif, dengan cara menelaah dan mengkaji peraturan perundang-undangan yang berlaku untuk digunakan sebagai dasar dalam melakukan pemecahan masalah dan dianalisis secara normatif kualitatif. Hasil penelitian menunjukkan bahwa proses Pengelolaan ADD telah mengikuti aturan dan petunjuk teknis yang telah diatur dalam peraturan perundang-undangan, namun dalam prosesnya masih belum optimal. Hal tersebut terlihat dari proses pelaporan dan pertanggungjawaban yang mengalami keterlambatan. Faktor yang menghambat pengelolaan Alokasi Dana Desa (ADD) yakni Rendahnya partisipasi masyarakat dalam mengibahkan tanahnya kepada Pemerintah Desa, Sarana dan Prasarana yang kurang memadai, Keterbatasan kualitas Sumber Daya Manusia Aparat pemerintah Desa di Desa Sabaru yang rata-rata berpendidikan SMA/SMK. Hal tersebut menyebabkan kurangnya pengetahuan tentang pengelolaan ADD dan petunjuk teknis pengelolaan ADD yang setiap tahun berubah. Fenomena ini menyebabkan tim pelaksana kegiatan ADD mengalami kesulitan dalam malaksanakan tugasnya serta komunikasi masyarakat yang kurang mampu mengutarakan pendapat di depan umum.
\end{abstract}

Kata kunci: Dana Desa, Wilayah Terpencil, Pelaporan Anggaran

\section{ABSTRACT}

The purpose of this study is to find out and analyze what factors influence the effectiveness of the law on the implementation of the Village Fund (VF) and Village Fund Allocation (VFA) programs for remote areas, particularly in Sabaru Village, Liukang Kalmas District, Pangkep Regency. This study uses qualitative research, by examining and reviewing the applicable laws and regulations for use as a basis for solving problems and analyzing normatively qualitatively. The results show that the ADD Management process has followed the rules and technical guidelines that have been regulated in the legislation, but the process is still not optimal. This can be seen from the process of reporting and accountability that is experiencing delays. Factors that hamper the management of Village Fund Allocation (VFA) are the low participation of the community in donating their land to the Village Government, Inadequate Facilities and Infrastructure, Limitation of the quality of Human Resources Village government officials in Sabaru Village who are generally educated at SMA/SMK. This causes a lack of knowledge about VFA management and VFA management technical guidelines that change every year. This phenomenon has caused the VFA activities implementing team to experience difficulties in carrying out their duties and public communication that is unable to express opinions in public.

Keywords: Village Funds, Remote Areas, Budget Reporting

\section{PENDAHULUAN}

Konstitusi Indonesia menyatakan bahwa Indonesia merupakan Negara Kesatuan yang berbentuk Republik, demikian sesuai bunyi Pasal 1 ayat (1) Undang-Undang Dasar
Negara Kesatuan Republik Indonesia Tahun 1945 dibagi atas daerah-daerah provinsi dan daerah provinsi itu dibagi atas kabupaten dan kota, yang tiap-tiap provinsi, kabupaten, dan kota itu mempunyai pemerintahan daerah, yang diatur de- 
ngan undang-undang (Pasal 18 ayat (1) Undang-Undang Dasar Negara Republik Indonesia Tahun 1945). Secara historis Indonesia memiliki desa yang merupakan cikal bakal terbentuknya masyarakat dan pemerintahan diIndonesia. Jauh sebelum bangsa-bangsa modern terbentuk, kelompok sosialsejenis desa atau masyarakat adat dan lain sebagainya, telah menjadi bagian yangpenting dalam suatu tatanan negara (Ndraha, 1991: 181).

Keberadaan desa di Negara Kesatuan Republik Indonesia kemudian secarayuridis normatif juga telah diatur, dimana desa telah diberikan atau diakui kewenangan-kewenangan tradisionalnya menurut Pasal 18B ayat (2) UUD NRITahun 1945 yang menegaskan bahwa:

"Negara mengakui dan menghormati kesatuan-kesatuan masyarakat hukum adat beserta hak-hak tradisionalnya sepanjang masih hidup dan sesuai dengan perkembangan masyarakat dan prinsip Negara Kesatuan Republik Indonesia yang diatur dalam Undang-Undang".

Jadi, menurut UUD 1945 pengakuan terhadap kesatuan masyarakat hukum adat termasuk di dalamnya adalah desa berserta hak-hak tradisionalnya harus didasarkan pada prinsip tetap dalam bingkai Negara Kesatuan Republik Indonesia (Syafrudin dan Na'a, 2010:5). Dengan adanya pengakuan terhadap kesatuan-kesatuan masyarakat hukum adat maka sudah semestinya perlu adanya pembangunan secara merata di berbagai daerah dalam pemerintahan desa yang dimana masyarakatnya merupakan kesatuan hukum adat (Budiono, 2005; Amiruddin dkk., 2010).

Agar dapat mempercepat pembangunan di segala bidang, maka upaya peningkatan dan pemerataan kemampuan Pemerintah Desa di seluruh Indonesia mutlak diperlukan. Salah satu strateginya adalah pembangunan bisa sampai ke desa. Tuntutan dibentuknya Undang-Undang Desa tersendiri yang terpisah dengan Undang-Undang Pemerintahan Daerah menunjukkan sering berubahnya peraturan perundang-undangan berdasarkan kepentingan pemerintah pusat maupun daerah yang membingungkan perangkat desa (Fauzan, 2006; Fadli, 2013).

Padahal kejelasan peraturan akanmembawa dampak positif pada pembangunan desa yang masih terkesan sangat banyak ketertinggalan di beberapa daerah.Lahirnya UndangUndang Nomor 6 Tahun 2014 tentang Desa menjadi bahan kajian menarik yang diharapkan memperkuat otonomi desa serta percepatan pembangunan. Kesatuan kewenangan skala lokal desa juga diperlukan untuk melakukan perencanaan Keuangan guna melangsungkan PelaksanaanPembangunan Desa. Untuk mendukung hal tersebut, di bidang anggaran setiapdesa di seluruh Indonesia akan mendapatkan dana yang penghitungan anggarannya didasarkan pada jumlah desa dengan pertimbangan diantaranya adalah jumlah penduduk, angka kemiskinan, luas wilayah, dan tingkat kesulitan geografis dalam rangka meningkatkan kesejahteraan dan pemerataan pembangunan desa (Budiman, kkn.bunghatta.ac.id., Online: diakses tanggal 17 Juli 2018)

Di sisi lain, UU Desa ini mengandung kekurangan salah satunya yaitu, dikatakan bahwa setiap desa akan mendapatkan dana alokasi dari Anggaran Pendapatan dan Belanja Negara (APBN) paling sedikit 10 persen setiap tahunnya. Maka, dapat diperkirakan setiap desa akan mendapatkan dana sekitar 1,2 hingga 1,4 miliar setiap tahunnya. Berdasarkan perhitungan dalam penjelasan UU Desayaitu, 10 persen dari dana transfer daerah menurut APBN untuk perangkat desasebesar Rp.59,2 triliun, ditambah dengan dana dari APBD sebesar 10 persen sekitar Rp.45,4 triliun. Total dana untuk desa adalah Rp. 104, 6 triliun yang akandibagi ke 72.944 desa se-Indonesia. Mengenai pengelolaan keuangan desa, lebih lanjut lagi dijelaskan didalam Peraturan Pemerintah Nomor 43 Tahun 2014 tentang PeraturanPelaksanaan Undang-Undang Nomor 6 Tahun 2014 tentang Desa dan Peraturan Menteri Dalam Negeri Nomor 113 Tahun 2014 tentang Pengelolaan Keuangan Desa, di mana disebutkan bahwa pengelolaan keuangan desa adalah serangkaian kegiatan yang meliputi perencanaan, pelaksanaan, penata usahaan, pelaporan dan pertanggung jawaban. Lebih lanjut, adanya suatu penguatan pengelolaan dan pengawasan keuangan desa yang baik mutlak diperlukan untuk mencegah atau setidaknya mengurangi kemungkinan penyimpangan serta terwujudnya tujuan pembangunan desa (Saparin, 1979; Salim dkk., 2013).

Pengawasan dilakukan untuk mengetahui terjadi atau tidaknya suatu penyimpangan dan bila terjadi, perlu diketahui sebab-sebab penyimpangan tersebut agar tidak ada kecenderungan penyelewengan oleh perangkat desa yang tidak bertanggung jawab (Sujamto, 1987: 56). Kekhawatiran lainnya juga terdapat pada para aparat desa yang bisa memanfaatkan dana desa dengan tidak benar dan melanggar hukum serta melakukan korupsi mengingat dari 72.944 desa yang ada di Indonesia belum ada basis data yang dimiliki Pemerintah Pusat terkait kualitas sumber daya manusia perangkat desa. Jumlah aparatur desa yang masih kurang dalam pengelolaan keuangan desa juga manjadi kekhawatiran yang patut diperhatikan (Hukumonline.com. online: diakses tanggal 17 Juli 2018). Jika kekhawatiran-kekhawatiran di atas tidak cepat dibenahi sebelun dikeluarkannya anggaran untuk desa, maka dapat diperkirakan kekhawatiran tersebut mungkin terjadi.

Diimplementasikannya Undang-Undang Desa menjadi perbincangan banyakkalangan dalam pengelolaan keuangan desa, yang di dalamnya terdapat pengelolaan sumber Daya desa. Pengelolaan dana desa yang diatur dalam UndangUndang Desa memacu kesiapan kepala desa dalam pelaksanaannya (Wijaya, 2003;Tjandra, 2006). Berbagai alasan dan faktor disampaikan oleh masyarakat terkait dengan kesiapan kepala desa dan aparatur desa, infrastruktur desa serta kepemimpinan kepala desa. Undang-Undang Desa memberikan kewenangan secara otonom kepada pemerintah desa dalam mengelola dan mengembangkan desanya. Masyarakat desa lebih sejahtera dengan berbagai program pemberdayaan dan pengelolaan sumber daya desa. Pemerintah desa dapat melakukan pola peningkatan ekonomi desa melalui Badan Usaha Milik Desa (BUMDes), mengatur Anggaran Pendapatan dan Belanja Desa (APBDes) serta melakukan berbagai pembangunan infrastruktur yang dapat menunjang peningkatan perekonomian desa. Dari desa membangun negeri menjadi terwujud.

Melimpahnya sumber daya desa memberikan peluang yang signifikan bagi pemerintah desa dalam membangun perekonomian desa dan kesejahteraan bagi masyarakat desa. Potensi-potensi tersebut harus dilakukan identifikasi secara baik dan dikembangkan melalui pemberdayaan kepada masyarakat secara berkesinambungan. Banyak sekali potensi yang belum tergali secara optimal dan maksimal serta belum dikelola secara baik. Banyak kendala yang melatarbelakangi, antara lain keuangan desa, sumber daya manusia desa dan infstruktur yang tidak mendukung. Dikucurkannya dana desa sejumlah 1 Milyar hingg 1,4 Milyar memberikan angin segar bagi desa untuk lebih maksimal dalam mengelola potensi desa dan mengembangkannya menjadi desa yang mandiri, berdaya 
guna dan berdaya saing tinggi mengingat Masyarakat Ekonomi ASEAN (MEA) sudah berlangsung, bahkan sampai pada tahun 2018 sekarang ini, beberapa desa telah mendapatkan total anggaran mencapai lebih dari 2 Miliyar. Ekonomi desa menjadi harapan pemerintahuntuk menjadi hilir dari pembangunan ekonomi pusat. Namun demikian, yang menjadi pertanyaan adalah bagaimana pemerintah desamelakukan pencegahan terhadap tindak pidana korupsi dalam pengelolaan sumber daya alam desa (Wijaya, 2003;Tjandra, 2006). Baik dalam pengambilan kebijakan, pengalokasian anggaran, maupun dalam pelaksanaan kebijakan. Sehingga ketakutan sebagian kalangan terhadap pelaksanaan Undang-Undang Desa, terutama dalam pengelolaan sumber daya desa dapat berjalan dengan baik danterhindar dari tindak pidana korupsi.

Hasil penelitian Thomas dan Metrejean dalam Yurniwati dan Rizaldi menjelaskan tidak adanya kontrol lingkungan menyebabkan peluang untuk perilaku korupsi. Pemerintah merupakan sistem pengendalian intern menyatakan bahwa lingkungan pengendalian adalah kondisi yang dibangun dan dibuat dalam sebuah badan pemerintah yang mempengaruhi efektivitas pengendalian internal. Miskin pengendalian menyediakan kontribusi yang signifikan terhadap ketidakefektifan pelaksanaan kegiatan.

Hasil penelitian Warsono dan Ruksamin(2014) mengenai The Obstacles of Implementation of Village Allocation Fund Program in the North Konawe Southeast Sulawesi dalam Journal of Management and Sustainability menjelaskan bahwa pengelolaan dana desa tidak akan terlaksana dan terimplementasi dengan baik jika tidak ada evaluasi dalam pelaksanaanya.

Contoh tentang kasus korupsi dana desa di Bangka Belitung yang dilakukan oleh kepala desa dan ketua BPD beserta jajarannya (Iskandar:2015). Kasusnya adalah dana yang seharusnya dimasukkan ke APBD desa berjumlah Rp.1 milyar berkurang menjadi Rp. 465 juta dan dibelanjakan 1 unit kendaraan truk seharga Rp. 340 juta sedangkan Rp. 25 juta dibagikan kepada anggota BPD di rumah kediaman ketua BPD, dan disinyalir sumbangan dana dari pihak ketiga disimpan di rekening pribadi serta adanya dugaan praktek gratifikasi dan penyalah gunaan wewenang oleh pemerintah desa. Kasus penyimpangan lainnya, tiga kepala desa dan seorang carik di kabupaten Kendal, Jawa Tengah, tersangkut kasus korupsi Alokasi Dana Desa dan tanah bengkok (Kompas. com). TLK diduga telah melakukan korupsi uang ADD dan kas desa sebesar Rp. 118,9 juta. SM diduga melakukan korupsi pada tahun 2014, dan WDD disangka korupsi Rp.66,81juta. Kasuslain, yaitu yang terjadi di Kepala Sebatang, Labuhan Batu Utara, Sumatera Utara. Kepala desa Zainuddin dituntut tujuh tahun penjara terkait kasus dugaan korupsi Alokasi Dana Desa. Akibat korupsi tersebut negara mengalami kerugian sebesar Rp. 204 Juta.

Pencegahan terhadap tindak pidana korupsi harus terus dilakukan, sampai ke level pemerintahan yang paling rendah. Sehingga terwujudnya ekonomi masyarakat desa yang meningkat dan tatanan pemerintahan yang baik dapat terwujud. Secara otomatis reformasi birokrasi dan good government berjalan paralel berdasarkan fungsi dankebutuhannya. Membangun negeri desa untuk kesejahteraan dan keadilan bagi seluruh rakyat. Biarlah proses demokrasi di daerah berjalan dengan memberdayakan rakyat di semua tingkatan untuk mencapai reformasi yang sesungguhnya karena reformasi adalah pembebasan manusia dari keterbelakangan dan pembo- dohan menuju kehidupan yang lebih baik (Marwan, 2018: 182).

Adapun tujuan dalam penelitian ini adalah untuk mengetahui dan menganalisis pelaksanaan program Dana Desa (DD) dan Alokasi Dana Desa (ADD) untuk wilayah terpencil khususnya di Desa Sabaru Kecamatan Liukang Kalmas Kabupaten Pangkep. Dan untuk mengetahui dan menganalisis faktor-faktor apa saja yang mempengaruhi efektifitashukum terhadap pelaksanaan program Dana Desa (DD) dan Alokasi Dana Desa (ADD) untuk wilayah terpencil khususnya di Desa Sabaru Kecamatan Liukang Kalmas KabupatenPangkep.http://ojs.unm.ac.id/index.php/JEST/index

\section{METODE}

Penelitian ini menggunakan pendekatan kualitatif, dilaksanakan di wilayah kepulauan Desa Sabaru Kecamatan Liukang Kalmas Kabupaten Pangkep yang berjarak sekitar 170 mil dari Kota Pangkep, yang ditempuh selama \pm 26 jam perjalanan jalur laut menggunakan kapal nelayan. Adapun pelaksanan penelitian dilakukan selama 2 (dua) bulan. Dalam penelitian ini penulis menggunakan tehnik purposive Sampling. Yaitu dengan menentukan beberapa informan dengan krateria yang telah ditentukan terlebh dahulu dan dianggap mengetahui serta mampu memberikan keterangan tentang masalah yang yang diteliti. Untuk memperoleh data yang relevan dan lengkap, penelitian ini menggunakan teknik mengumpulkan data primer dan sekunder. Adapun teknik pengummpulan data primer yang digunakan dalam penelitian ini adalah, Observasi, Wawancara, dan Dokumen. Penganalisaan data dalam penelitian ini, dilakukan menggunakan pendekatan indukatif konstektual yaitu memulai dari informasi-informasi empirik yang diperoleh kemudian dibangun konsep-konsep kearah pengembangaan suatu teori substansi, teori yang bertolak dari data dan cerna dengan pengalaman lalu.

\section{HASIL DAN PEMBAHASAN}

\section{1) Kasus Korupsi ADD dan DD di Desa Sabaru Keca-} matan Liukang Kalmas Kabupaten Pangkep

Kasus korupsi alokasi dana desa Muhammad Usman Bin Rifai dimana tersangka Lahir di Sumenep (Jawa timur), Pada tanggal 16Juni 1965, Umur 53 Tahun, Suku Jawa, Agama Islam, Kewarganegaraan Indonesia, Pendidikan Terakhir SLTA, Pekerjaan Kepala Desa, Alamat sekarang Desa Sabaru, Kec. Liukang Kalmas, Kab. Pangkep, Nomor Handphone : 082348325408, NIK.KTP 7310021606650001. Berdasrakan keterngannya dalam perkara dugaan Tindak Pidana Korupsi Penyalagunaan ADD (Alokasi Dana Desa ) dan Dana Desa (DD) Desa Sabaru Kec. Liukang Kalmas Kab.Pangkep Tahun Anggaran 2014, 2015 dan 2016, sebagaimana dimaksud dalam UU No. 31 tahun 1999 Jo. UU No. 20 tahun 2001, tentang Pemberantasan Tindak Pidana Korupsi, berdasarkan Laporan Polisi Nomor: LPA/44/VI/2018/SPKT/Res Pangkep, tanggal 29Juni 2019 dan Surat Perintah Penyidikan Lanjutan Nomor Sp. Sidik /55.A/I/2019/ Reskrim, tanggal 21Januari 2019.

Dalam berita acara pemeriksaan terhadap tersangka diperoleh salah satu jawaban Saya Jelaskan bahwa memang benar barang-barang yang dijual di Toko Sumber Jaya tersebut sebagian besar tidak saya beli di toko sumber jaya, karena barang-barang tersebut saya beli dari Pulau Jawa dan saya jual kembali di Toko saya di Pulau Sabaru, sehingga untuk 
pengadaan barang-barang tersebut diatas, hanya saya ambil langsung dari toko saya, sedangkan untuk nota toko Sumber Jaya saya peroleh dari seorang teman dari wilayah kepulauan Kalmas, namun saya sudah lupa namanya.

\section{2) Proses Pencairan, Penyaluran dan Pelaksanaan ADD dan DD di Desa Sabaru Kecamatan Liukang Kalmas Kabupaten Pangkep}

Alokasi Dana Desa (ADD) adalah Alokasi Dana ke Desa dengan perhitungan dari Dana Perimbangan yang diterima oleh Kabupaten sebesar 10\% setelah dikurangi dengan Dana Alokasi Khusus (DAK). Pengelolaan ADD meliputi Proses Perencanaan, Pelaksanaan, Penatausahaan, Pelaporan dan Pertanggung Jawaban. Semua proses ini dijalan oleh Pemerintah Desa didampingi oleh Tim Pendamping Kecamatan. Tidak hanya itu, masyarakat juga ikut berpartisipasi dalam pengawasan ADD. Sebelum Merencanakan Alokasi Dana Desa (ADD), terlebih dahulu dilakukan penentuan besaran ADD. Penentuan besarnya Dana ADD yang akan diterima setiap desa di Kabupaten Pangkep ditentukan berdasarkan penghitungan ADD Minimal dan ADD Proporsional. ADD Mini-mal merupakan dana yang dialokasikan untuk ADD yang dibagi secara merata kepada seluruh desa se-Kabupaten Pangkep. Sedangkan ADD Proporsional ditentukan berdasar-kan nilai bobot Desa yang ditentukan dan dirumuskan oleh Tim Fasilitasi Kabupaten serta ditetapkan dalam Keputusan Bupati.

Khusus untuk Alokasi Dana Desa Proporsional (ADDP) di hitung dengan memperhatikan jumlah penduduk, angka kemiskinan, luas wilayah, dan indeks kesulitan geografis desa setiap di Kabupaten Pangkep. Alokasi Dana Desa Minimal sebesar $60 \%$ dan alokasi Dana Desa Propersional sebesar 40\%. Alokasi Dana Desa Proporsioanl di hitung berdasarkan data jumlah penduduk, angka kemiskinan, luas wilayah, dan indeks kesulitan geografis yang bersumber dari kementrian yang berwenang dan/atau lembaga yang menyelenggarakan urusan Pemerintahan di bidang Statistik.

\section{a. Perencanaan}

Salah satu yang dapat direncanakan dalam hal tersebut adalah cara mengalokasikan dana desa dengan sebaik-baiknya. Pada tahap perencanaan penggunaan ADD didahului dengan Musyawarah Perencanaan Pembangunan Desa (Musrenbangdesa) dengan melibatkan $\mathrm{BPD}$, LPMD, dan tokoh masyarakat lainnya, perencanaan Alokasi Dana Desa (ADD) dilakukan dengan menjaring aspirasi dan kebutuhan masyarakat melalui musyawarah desa. Alokasi Dana Desa (ADD) adalah salah satu pendapatan desa yang penggunannya terintregasi dengan Anggaran Pendapatan dan Belanja Desa (APBDes). Oleh karena itu, program perencanaan dan kegiatannya disusun melalui forum Musyawarah Perencanaan Pembangunan Desa.

Pada Proses Perencanaan Alokasi Dana Desa (ADD) diawali dengan rapat perdusun, Untuk menyusun rencana Kegiatan tersebut harus melibatkan partisipasi seluruh komponen yang ada di Desa baik lembaga kemasyarakatan maupun masyarakat umum melalui forum musyawarah tingkat Desa.

Sebelum melaksanakan Musrenbang Desa, Pemerintah Desa membuat format RKP Desa yang melibatkan masyarakat. Setelah itu, Pemerintah Desa membuat daftar kebutuhan masyarakat yang akan disampaikan pada saat Musrenbang Desa.

Melaksanakan Musrenbang Desa Pemeritah Desa melakukan Pra Rapat untuk menghasilkan program kegiatan yang ingin terkaiat dengan keterlibatan masyarakat secara umum dalam Musrenbang Desa, apakah masyarakat Desa Sabaru sudah mengetahui bahwa Pemerintah Desa mendapatkan sumber Dana dari Pemerintah Kabupaten yaitu Alokasi Dana Desa (ADD) Salah satu informan yang berasal dari Perangkat Desa, Bengga mengatakan bahwa:

"Semua masyarakat yang ada di Desa Sabaru sudah tau, kalau Pemerintah Desa mendapatkan Dana ADD“ (Hasil Wawancara, 13 Juli 2019).

Wawancara yang dilakukan dengan Tokoh Masyarakat yang ada di Dusun Labempa, untuk mengetahui pengetahuan mereka mengenai Alokasi Dana Desa (ADD) dan bagaimana cara Pemerintah desa memberikan informasi kepada masyarakat jika ada kegiatan. Tokoh masyarakat tersebut menyatakan bahwa :

"Saya tau kalau pemerintah desa mempunyai sumber pendapatan dari Kabupaten yang di sebut ADD dan Biasanya kalau ada kegiatan di Kantor Desa seperti Musrenbang kita di undang, ada perangkat desa yang bawa undangan dirumah, tapi tidak tau untuk masyarakat bagaimana cara penginformasiannya" (Hasil Wawancara, 27 Juli 2019).

Sementara itu, di tempat yang terpisah juga melakukan Wawacara dengan Tokoh Masyarakat yang ada di Dusun Anukaraja, Tokoh masyarakat tersebut menyatakan bahwa: "Saya biasa dengar tapi kurang tau apa yang di maksud ADD, Kalau untuk pemberitahuan kepada masyarakat biasanya ada dari perangkat Desa yang umumkan di mesjid pada saat sudah sholat jum'at" (Hasil Wawancara 27 Juli 2019).

Pelaksanaan dalam Kegiatan Kepala Desa membentuk TPK (Tim Pelaksana Kegiatan) ADD, Hal ini diterangkan oleh Narasumber, H.A.Sampewali bahwa :

"Untuk pelaksanaan kegiatan Alokasi Dana Desa (ADD) ada Tim Pelaksana Kegiatan tersendirinya, tujuanya untuk menyusun Rencana Anggaran Biaya (RAB) dan segala sesuatu yang berkaitan dengan ADD Tim Pelaksana Kegiatan wajib melaporkan kepada Kepala Desa untuk lebih jelasnya ada di SK pembentukan TPK” (Hasil Wawancara, 25 Juli 2019).

Setelah Pemerintah Desa membuat Format RKP Desa, Tim pelaksana kegiatan ADD menyusun format Rencana Anggaran Biaya (RAB) hal ini di terangkan oleh Ramayana bahwa: "Kita menyusun Rencana Anggaran Biaya (RAB) berdasarkan data harga Pasar di situlah kita bahas berapa anggaran yang digunakan untuk pembangunan misalnya pembangunan jalan Tani memerlukan berapa anggaran"(Hasil Wawancara, 26 Juli 2019).

Proses MusrenbangDesa dipimpin oleh Kepala Desa dan dihadiri oleh Camat, Dalam proses Musrenbang dibicarakan segala kebutuhan masyarakat baik yang telah diketahui sebelumnya maupun yang baru disampaikan masyarakat. Hal ini berdasarkan hasil wawancara dengan mantan sekertaris Desa Sabaru, Anwar yang mengatakan: "Pada saat Musrenbang Desa, kan dipimpin oleh Kepala Desa dan dihadiri oleh pak camat, pak desa pemimpin MusrenbangDesa, disitumi diminta apa usulannya masyarakat dari tiap dusun nanti diusulkan di Kecamatan “ (Hasil wawancara,26 Juli 2019).

Kegiatan selanjutnya dalam proses Perencanaan penggunaan Alokasi Dana Desa (ADD) setelah penyusunan usulan prioritas rencana kegiatan Desa yang dibiayai ADD adalah penyusunan Rencana Penggunaan Dana (RPD) Dalam RPD Pemerintah Desa harus mengacu pada usulan rencana kegiatan desa yang telah disepakati dan disahkan dalam Musyawarah Desa. Hal ini berdasarkan hasil wawancara dengan Bendahara Desa Sabaru, Junaeda mengatakan: "Dalam Rencana Penggu- 
naan Dana (RPD) Pemerintah Desa harus mengacu pada usulan rencana kegiatan desa yang telah disepakati dan disahkan dalam Musyawarah Desa" (Hasil Wawancara, 25 Juli 2019) .

Berdasarkan pada hasil Musrenbang Desa, Pemerintah Desa harus membuat RKPDesa yang memuat tentang Rencana Penyelenggaraan pemerintahan Desa, Pelaksanaan, Pembangunan, Pembinaan Masyarakat dan Pemberdayaan Masyarakat Desa karena RKPDesa merupakan Penjabaran Dari RPJMDes untuk jangka waktu 1 Tahun.Hal ini di terangkan oleh Ramayana sebagai Tim Pelaksana Kegiatan ADD, bahwa: "Hasil dari Musrenbang Desa harus di buatkan RKPD Desa yang merupakan penjabaran dari RPJMDesa, RKPDesa itu rencana Kerja pembagunan Desa yang jangka waktunya 1 tahun" (Wawancara, 26 Juli 2019)

\section{b. Pelaksanaan}

Pelaksanaan adalah suatu tindakan atau pelaksanaan dari sebuah rencana yang sudah disusun secara matang dan terperinci, implementasi biasanya dilakukan setelah perencanaan sudah dianggap siap. Dalam pelakasanaan program bantuan kepada Pemerintah Desa, Setiap tahun Bupati Pangkep mengeluarkan surat yang mengatur tentang pelaksanaan suatu program yang dapat membantu Perangkat Desa. Untuk menindak lanjuti Surat Keputusan Bupati Pangkep tersebut maka, dikeluarkan Peraturan Bupati Pangkep nomor 2 tentang Petunjuk Teknis tentang Aloksi Dana Desa yang di sebar keseluruh desa yang ada di Kabupaten Pangkep. Petunjuk Teknis tersebut dimaksudkan sebagai pedoman Perangkat Desa. Pelaksanaan ADD Kepala Desa bertindak sebagai penanggungjawab pengelolaan kegiatan yang bersumber dari ADD. Hal ini dibenarkan oleh Kepala Desa Sabaru, H.A. Sampewali: "Saya sebagai Penanggung jawab saja untuk TPK ADD (Tim pelaksana kegiatan) sudah ada di bentuk, untuk tim pelaksana kegiatanADD tingkat Desa 3 orang terdiri dari Perangkat Desa, LPMD, dan masyarakat" (Wawancara 25 Juli 2019)

Pembangunan yang lakukan Pemerintah Desa lebih cenderung mengutamakan Dusun tertentu. Hal tersebut di peroleh dari informan yang berasal dari Dusun Lebong, bahwa :"Pembangunan yang di lakukan oleh pemerintah Desa kebanyakan di Dusun Anukaraja, padahal kita juga di dusun Lebong butuh Cekdam" (Hasil wawancara, 23 Juli 2019)

Masyarakat berharap Pemerintah semua Desa memiliki BUMDES, hal tersebut di terangkan oleh masyarakat yang berasal dari Dusun Labempa, Bahwa: "Kami sebagai masyarakat biasa, khususnya yang tidak punya pekerjaan berharap Pemerintah Desa memiliki BUMDes seperti bengkel" (Hasil Wawancara 2 Juli 2019)

Berdasarkan hasil wawancara yang dilakukan, di sisi lain Pemerintah Desa Sabaru juga mendapat respon yang Positif dalam Pelaksanaan Penggunaan ADD, khususnya dalam melaksanakan Pembangunan. Dalam melakukan pem-bangunan Kepala Desa Sabaru selalu ikut berpartisipasi dalam hal memantau proses pembangunan. Hal ini di ungkapkan oleh masyarakat yang berasal dari Dusun Anukaraja, Supu mengakatan: "Biasanya kalau ada pembangunan yang di laksanakan, Kepala Desa turun langsung membantu dan selalu memantau setiap proses pembangunan " (Hasil Wawancara 2 Juli 2019).

Di tempat yang terpisah, Kepala Dusun Lebong mengatakan jika pembangunan di tahap pertama belum rampung, maka di alihkan ke tahap berikutnya. H.Muh Edi mengatakan bahwa: "Jika pembangunan di tahap pertama tidak terlaksana/ tidak rampung, maka dialihkan ketahap kedua"(Hasil Wawancara, 26 Juli 2019).

Hal tersebut sesuai dengan yang diungkapkan oleh Ketua PMD Desa Sabaru, jika Dana di tahap pertama tidak mecukupi, maka menggunakan Dana pembangunan yang tahap kedua. Anwar mengatakan bahwa :

"Biasanya kalau pembangunan di tahap pertama belum selesai, terus dananya tidak mencukupi kita menggunakan sebagian dana pembangunan untuk tahap kedua, nanti pada saat Pertanggung Jawaban pintar pintarnya Bendahara Desa dan sekertaris Desa mengkalkulasi, yang penting tidak ada penyalahgunaan dana, kalau masalah seperti ini bisa karena untuk kepentingan kita bersama "(Hasil Wawancara, 26 Juli 2019)

\section{c. Penatausahaan}

Penatausahaan Keuangan Desa adalah seluruh kegiatan keuangan yang dilakukan oleh pemerintahan desa yakni Bendahara Desa terdiri dari Penatausahaan penerimaan dan Penatausahaan pengeluaran serta pelaporan pertanggungjawabannya kepada pihak yang berkepentingan. Kepala Desa memegang kuasa tertinggi dalam pengelolaan keuangan Desa karena jabatannya sebagai kepala pemerintahan di tingkat Desa. Dalam pelaksanaannya, kepala Desa dibantu oleh Pelaksana Teknis Pengelolaan Keuangan Desa (PTPKD) yang merupakan perangkat desa yang ditunjuk kepala Desa, PTPKD atau Pelaksana Teknis Pengelolaan Keuangan Desa merupakan unsur perangkat desa yang membantu Kepala Desa untuk melaksanakan pengelolaan keuangan desa. Bendahara di jabat oleh staf pada Urusan Keuangan. Bendahara mempunyai tugas menerima, menyimpan, menyetorkan atau membayar, menatausahakan, dan mempertanggung jawabkan penerimaan pendapatan desa dan pengeluaran pendapatan desa dalam rangka pelaksanaan APBDesa. Bendahara Desa wajib melakukan pencatatan setiap penerimaan dan pengeluaran serta melakukan tutup buku setiap akhir bulan secara tertib dan Bendahara Desa wajib mempertanggungjawabkan uang melalui laporan pertanggungjawaban. Laporan pertanggungjawaban disampaikan setiap bulan kepada Kepala Desa paling lambat tanggal 10 bulan berikutnya. Dokumen yang digunakan oleh bendahara dalam melakukan penatausahaan penerimaan dan pengeluaran antara lain, buku kas umum, buku kas pembantu pajak dan buku bank. Buku kas umum digunakan untuk mencatat seluruh bukti transaksi keuangan desa. Buku kas pembantu pajak digunakan untuk mencatat bukti transaksi terkait dengan pemungutan maupun penyetoran pajak oleh bendahara desa. Buku bank digunakan untuk mencatat bukti transaksi terkait dengan penerimaan maupun pengeluaran melalui bank.

Berdasarkan Peraturan Bupati Pangkep Nomor 51 tentang pengelolaan keuangan Desa pada pasal 50 tentang Penatausahaan APBDesa pada ayat 2 (Dua) Bendahara Desa wajib menyelenggarakan Penatausahaan terhadap seluruh penerimaan, penyimpanan, pembayaran, penatausahan, yang menjadi tanggung jawabnya serta melakukan tutup buku setiap akhir bulan secara tertib. Hal ini sesuai dengan hasil wawancara dengan Kepala Desa Sabaru, H.A.Sampewali menyatakan bahwa: "Setiap Bulan Bendahara Desa Melaporkan Kondisi Keuangan Desa” (Hasil Wawancara, 1 Agustus 2019)

Selain tahapan penatausahaan yang di atur, Bendahara Desa wajib melakukan pencatatan terhadap seluruh transaksi yang berupa penerimaan dan pengeluaran. Bendahara Desa 
melakukan pencatatan secara sistematis atas transaksi-transaksi keuangan yang terjadi, terkait dengan pernyataan tersebut, di tempat yang terpisah wawancara dilakukan dengan Bendahara Desa Sabaru, Junaeda mengatakan bahwa :

"Pada saat pengeluaran kas berupa belanja untuk melaksanakan operasional kegiatan Desa dan program-program Desa, kita harus simpan bukti-bukti transaksi keuangan, baik kas masuk maupun kas keluar, kemudian mencatatnya ke dalam buku kas umum, buku kas pembantu pajak dan buku bank kemudian desa melakukan penutupan pada setiap bulannya atas buku kas umum, buku kas pembantu pajak dan buku bank, sebagai laporan pertanggungjawaban kepada kepala desa". (Hasil Wawancara, 1 Juli 2019)

Hal tersebut sesuai dengan yang di terangkan oleh Kepala Desa, Sabaru bahwa Bendahara Desa wajib mencatat semua pengeluaran dan penerimaan Keuangan Desa. H.A.Sampewali Mengatakan: "Dalam melakukan pengeluaran dan penerimaan Keuangan Desa Bendahara wajib mencatat semua kedalam buku Kas dan bendahara Desa telah telah melaksanakannya sesuai dengan aturan yang ada "(Hasil Wawancara 1 Juli 2019)"

Sementara di tempat yang terpisah juga dilakukan Wawancara dengan Bendahara Desa Sabaru, untuk mengetahui kendala yang dialami pada saat melakukan Penatausahaan Keuangan Desa. Kendala yang dilami pada saat melakukan Penatausahaan adalah belum mahirnya menggunakan komputer dan belum adanya pelatihan yang dilaksanakan oleh pihak yang berwenang. Hal tersebut diterangkan oleh, Junaeda bahwa:

"Kendala yang dialami karena baru dilantik tahun lalu, belum mahir menggunakan komputer dan tidak adanya pelatihan khusus untuk Bendahara baru apalagi faktor umur, pada Tahun 2016 ada tawaran dari Mahasiswa untuk mengadakan Pelatihan komputer untuk perangkat Desa tapi tidak di berikan Izin oleh BPMD karena Untuk Dana Pemberdayaan tidak boleh digunakan untuk Aparat Desa, Pelatihan bisa dilaksanakan asalkan di ambil dari dana SDM " (Hasil Wawancara 25 Juli 2019)

Berdasarkan dari hasil Wawancara tersebut, Dalam melaksanakan Penatausahaan yang di lakukan oleh Pemrintah Desa Sabaru dalam hal ini Pelaksana Tugas Pengelolaan Keuangan Desa (PTPKD) sudah sesuai dengan Peraturan yang ada di Peraturan Bupati Pangkep Nomor 51 tahun 2015 tentang Pengelolaan Keuangan Desa dan bahwa dengan adanya Penatausahaan yang dilakukan Bendahara Desa berupa Buku Kas Umum, Buku Kas, Pembantu Pajak dan Buku Bank sangat mempermudahkan BPD dan masyarakat untuk mengetahui ada atau tidak adanya penyelewengan dari dana yang begitu besar dipegang atau dikelola Pemerintah Desa.

\section{d. Pelaporan}

Bentuk Pelaporan atas kegiatan-kegiatan dalam APBDesa mempunyai dua tahap Pelaporan. Pertama, Laporan berkala yaitu Laporan mengenai pelaksanaan penggunaan Dana ADD yang dibuat secara rutin setiap semester dan atau 6 Bulan sesuai dengan tahapan pencairan dan pertanggung jawaban yang berisi realisasi penerimaan dan belanja ADD. Kedua, Laporan akhir dari penggunaan ADD mencangkup pelaksanaan dan penyerapan dana, masalah yang dihadapi dan rekomendasi penyelesaian hasil akhir penggunaan ADD. Kedua laporan ini dibuat oleh Kepala Desa, Sekretaris Desa dan Bendahara Desa.

Laporan berkala dan laporan akhir Penggunaan ADD harus di buat sesuai dengan Peraturan Bupati. Penyampaian laporan atas realisasi penggunaan dana yang dibiayai oleh ADD dilaksanakan secara berjenjang oleh Kepala Desa Kepada Tim Pendamping Kecamatan, kemudian Tim Pendamping Kecamatan membuat Laporan Tingkat Desa. Laporan ini selanjutnya dilaporkan kepada Bupati melalui BPMPDK Kabupaten Pangkep sebagai dasar untuk melakukan penyaluran dana. Dalam proses penyampaian laporan penggunaan Alokasi Dana Desa (ADD), Kepala Desa yang bersangkutan dituntut untuk menyampaikan laporan tepat waktu. Apabila laporan tersebut tidak tepat waktu atau terlambat dilaporkan maka Bupati berhak untuk menunda pencairan dana untuk tahap selanjutnya dan pengurangan dana yang bersumber dari APBD Kabupaten untuk tahun berikutnya sesuai dengan penelian Tim pengendali Kabupaten dan tim fasilitasi Kecamatan yang di bentuk dengan Keputusan Bupati. Penerapan proses pelaporan yang telah ditentukan dalam Peraturan Bupati, penulis melakukan penelitian terhadap proses pelaporan yang dilakukan oleh pemerintah Desa di Desa Sabaru dalam melaksanakan pelaporan Alokasi Dana Desa (ADD), pelaporan penggunaanya dilaksanakan dalam dua tahap yaitu tahap semester pertama dan semester dua hal tersebut di terangkan oleh sekertaris Desa Sabaru, Aslidayanti yang meyatakan bahwa :

"Untuk Pengelolaan ADD memang sudah ada Aturannya. biasanya kita pedomani Peraturan Bupati Pangkep nomor 2 Tentang Petunjuk Teknis Alokasi Dana Desa dan Perbup nomor 51 tahun 2015 Tentang Pengelolaan Keuagan Desa. Pelaporan penggunaan ADD dilaporkan dalam dua tahap yaitu tahap semester pertama paling lambat akhir bulan juli dan Semester dua paling lambat bulan Juli" (Wawancara, 20 Juli 2019).

Berdasarkan hasil wawancara bahwa pelaporan tahap pertama yakni laporan berkala dilaksanakan pada bulan Juli 2019 dan diserahkan paling lambat akhir bulan Juni ke BPMDK dan BPKD untuk melakukan pencairan dana. Selanjutnya, untuk laporan akhir dilaksanakan bulan Agustus dan diserahkan paling lambat bulan Juli 2019. Namun, sebelum diterima oleh BPMDK dan BPKD, Laporan tersebut di veryfikasi oleh Tim Pendamping Kecamatan. Hal ini sesuai dengan yang disampaikan oleh Kepala Seksi Keuangan dan Aset Desa Dinas PMD Kab.Pangkep Syarifah Chaerul Yaman mengatakan:

"Pelaporan ADD di kerja di desa kemudian verifikasi untuk pencairan nanti masuk di Kecamatan kan di Kecamatan ada di bilang tim pendamping Kecamatan, dan di Kecamatan lah seharusnya berfungsi untuk memferifikasi kemudian di kasi masuk di PMD dan keuangan" (Wawancara pada tanggal 20 Juli 2019).

Berdasarkan hasil wawancara yang dilakukan, pelaporan penggunaan ADD terdiri atas Laporan Berkala dan Laporan Akhir. Proses pembuatan Laporan Berkala dan Laporan Akhir terbilang sama namun berbeda pada lampiran laporan.

Hasil vertifikasi terhadap surat permohonan pencairan ADD beserta lampirannya, apabila dianggap belum memenuhi syarat, akan di kembalikan ke Desa untuk di sempurnakan. Hal ini sesuai yang di katakana oleh Kepala Desa Sabaru, H.A.Sampewali bahwa :

"Terkadang dalam proses Pelaporan pernah mengalami kesalahan yang periksa di BPMPDK Kabupaten, karena meskipun dikecamatan menyatakan sudah baik tapi kalau di BPMPDKbilang salah maka harus diperbaiki lagi" (Hasil Wawancara, 25 Juli 2019 2017) 
Sementara dalam proses Permohonan Pencaiaran Dana ADD, jika Admistrasi yang di butuhkan belum memenuhi syarat, maka dikembalikan kepada Desa terkait, karena fungsi BPMDK sebagai Pembinaan. Hal tersebut sesuai dengan yang disampaikan oleh Kepala Seksi Keuangan dan Aset Desa Dinas PMD Kab.Pangkep Syarifah Chaerul Yaman menyatakan:

"Untuk SPP Desa yang dikembalikan setelah tim kami verifikasi, sudah cocok tidak admistrasi yang kita butuhkan kalau ada yang tidak sesuai kita kembalikan untuk di perbaiki karena fungsi kita sebagai pembinaan beda dengan inspektorat karena dia pengawasan dia mencari apa yang menjadi temuan kalau kita tidak mencari untuk melakukan pembinaan. (Hasil Wawancara 20 Juli 2019 )

Pada proses pelaksanaan Pelaporan Alokasi Dana Desa (ADD), jika Tahap pertama telah di buatkan SPJ/Laporan realisasi maka pencairan tahap kedua bisa dilakukan. Hal ini diterangkan oleh Mantan Sekertaris Sabaru, Anwar bahwa :

"Dalam melaksanakan Pelaporan dilakukan dua tahap, apabila tahap petama telah dibuatkan SPJ maka pencairan tahap kedua dilaksnakan dan tidak mutlak per enam bulan asalkan dana tahap pertama habis dan di buatkan laporan realisasi maka tahap kedua bisa dicairkan" (Hasil Wawancara 26 Juli 2019)

Terkait dengan Proses pencairan di tempat yang terpisah penulis melakukan wawancara dengan Kepala Seksi Keuangan dan Aset Desa Dinas PMD Kab.Pangkep Syarifah Chaerul Yaman S.Sos mengatakan bahwa: "Untuk mendapatkan tahap pertama masuk tahap kedua, untuk pencairan tahap kedua masuk ketahap pertama. tapi pelaporannya harus tetap di masukkan sebagai admistrasi keuangan" (Hasil Wawancara. 20 Juli 2019)

Sementara itu, Mantan Sekertaris Desa Sabaru tersebut juga mengatakan bahwa: "Laporan ADD dibuat tersendiri, karena APBdes itu Di APBdeskan tercover semua sumber dana, ADD,Dana Desa, Bagi Hasil Pajak terkafer semua di APBDES berapa jumlah pendapatanta 1 tahun. nanti pelaporanya ada di bilang realisasi ADD, ada juga Dana Desa tersendiri" (Hasil Wawancara 26 Juli 2019)

Disisi lain penulis juga melakukan wawancara kepada salah satu Perangkat Desa di Desa Sabaru. Salah satu informan juga menerangkan bahwa memang benar Laporan ADD tahap II belum dilaporkan. Hal tersebut di jelaskan oleh Sustina: "Laporan ADD belum selesai karena Pegawai senior sibuk dengan urusan pribadi masing-masing dan kita sudah dapat surat teguran dari BPMDK karena belum setor ke kantor" (Hasil Wawancara, 13 Juli 2019)

Dari hasil wawancara diatas maka penulis menyimpulkan bahwa dalam proses pelaporan dalam pengelolaan Aloksi Dana Desa (ADD) oleh Pemerintah Desa Sabaru ke BPMDK Kabupaten Pangkep masih belum sesuai dengan Peraturan yang telah ditetapkan dimana pemerintah Desa belum mampu untuk melaporkan kegiatan sesuai dengan jadwal waktu yang ditentukan Terlihat dari belum dirampungkannya Laporan Realisasi Tahap II.

\section{e. Pertanggungjawaban}

Pertanggungjawaban Alokasi Dana Desa (ADD) terintegrasi dengan Pertanggungjawaban APBDesa, sehingga pertanggung jawaban tersebut adalah Pertanggung jawaban APBdesa. Pertanggungjawaban tersebut dibuat dalam bentuk Laporan Penyelenggaraan Pemerintahan Desa (LPPD) setiap akhir tahun dan bentuk susunan laporan penyelenggaraan pemerintahan Desa mengacu pada Peraturan Bupati Pangkep
Nomor 51 tahun 2015 Tentang Pengelolaan Keuangan Desa. Pembuatan Laporan Pertanggungjawaban yang dilakukan Pemerintah Desa khususnya Sekertaris Desa memilih menggunakan jasa pihak ketiga, karena Sekertaris Desa Sabaru tergolong Sekertaris baru dan belum mengetahui proses pembuatan LPPD. pihak ketiga yang dimaksud di Desa Sabaru adalah Sekretaris Desa yang lama dan sekarang menjabat sebagai Ketua LPMD.

Adapun teknis pembuatan Laporan Pertanggungjawaban telah diatur dalam Peraturan Bupati Pangkep Nomor 2 tahun 2016 tentang Petunjuk Teknis Alokasi Dana Desa dan Peraturan Bupati Pangkep Nomor 51 tahun 2015 tentang Pengelolaan Keuangan Desa. Hal ini sesuai dengan hasil Wawancara dengan Kepala Seksi Keuangan dan Aset Desa Dinas PMD Kabupaten Pangkep Syarifah Chaerul Yaman mengatakan bahwa: "Kami telah membagikan pedoman petunjuk teknis ADD ke setiap desa yang ada di Kabupaten Pangkep Di dalamnya sudah terdapat format Pelaporan dan format lainnya."( Hasil Wawancara tanggal 20 Juli 2019).

Sesuai dengan Peraturan Bupati Pangkep Nomor 2 tahun 2016 tentang Petunjuk Teknis Alokasi Dana Desa pada bab VII tentang Pertanggungjawaban pada pasal 12 bahwa dalam melakukan Pertanggungjawaban berisi tentang :

a. Tunjangan Kepala Desa dan Perangkat desa,

b. Tunjangan BPD,

c. Tunjangan Imam Desa, imam Dusun dan Guru Mengaji,

d. Tunjangan Bendahara Desa.

e. Belanja Operasional Pemerintah Desa, BPD, dan Lembaga

Kemasyarakatan

f. Belanja sumber Daya Manusia

g. Biaya Perjalanan Dinas

Pembuatan Laporan Pertanggungjawaban tersebut, perangkat Desa yakni Sekretaris Desa didampingi oleh Tim Pendamping Tingkat Kecamatan. Namun, tugas yang dilakukan oleh Tim Pendamping tersebut belum maksimal. Hal ini sesuai dengan hasil wawancara oleh Kepala Desa Sabaru, H.A.Sampewali mengatakan bahwa: "Tim Pendamping Tingkat Kecamatan yang ditugaskan untuk melakukan Pembinaan belum bekerja secara maksimal" (Hasil Wawancara 1 Juli 2019).

Selain itu, realitas yang terjadi di Desa Sabaru bahwa pembuatan Laporan Pertanggungjawaban tergolong lambat. Hal ini dikarenakan Sekretaris baru kurang paham terhadap tugas tersebut. Akibatnya, pembuatan Laporan ini masih menunggu kesempatan dan waktu dari mantanSekretaris Desa sebelumnya. Hal ini sesuai dengan hasil wawancara dengan Sekretaris Desa Sabaru, Aslidayanti mengatakan bahwa: "Sementara ini kami baru menyusun LPPD (Laporan PertanggungJawaban Pemerintah Desa) sebenarnya sudah agak terlambat" (Hasil Wawancara 1 Juli 2019)

Dalam setiap pengeluaran Keuangan Desa, Bendahara Desa wajib menyimpan bukti yang berupa nota pembelanjaan, karena dalam Laporan Pertanggungjawaban harus di sertai dengan nota tersebut, Hal tersebut di terangkan oleh Bendahara Desa Sabaru, Junaeda bahwa: "Setiap melakukan pengambilan barang di toko harus disertai dengan nota sebagai bukti pembelanjaan yang akan dilampirkan pada saat membuat Pertanggung Jawaban nantinya"(Hasil Wawancara 1 Juli 2019 ).

Pembuatan Pelaporan Pertanggungjawaban ini dimaksudkan agar setiap kegiatan yang dilakukan oleh Pemerintah Desa berdasarkan aturan yang ditetapkan dan tidak menyim- 
pang. Hal ini pun merupakan wujud transparansi Pemerintah Desa kepada masyarakat. Namun, realitas yang terjadi di Desa Sabaru bahwa kegiatan laporan pertanggungjawaban tidak direncanakan dan dilaksanakan dengan baik. Hal ini terlihat dengan keterlambatan pembuatan laporan pertanggungjawaban yang dilakukan.

\section{Faktor-faktor yang mempengaruhi Pengelolaan Alokasi Dana Desa (ADD) di Desa Sabaru Kecamatan Liukang Kalmsa Kabupaten Pangkep}

Alokasi Dana Desa (ADD) merupakan salah satu sumber Keuangan Desa yang diterima dari bagi hasil Dana Perimbangan setelah dikurangi Dana Alokasi Khusus (DAK) minimal $10 \%$ akan digunakan oleh Pemerintah Desa dalam melaksanakan pemerintahannya. Dalam Kegiatan Pengelolaan Alokasi Dana Desa (ADD) tersebut dipengaruhi oleh berbagai faktor baik yang sifatnya mendukung maupun menghambat proses. Adapun faktor-faktor yang mempengaruhi Pengelolaan Alokasi Dana Desa (ADD) di Desa Sabaru, Kecamatan Liukang Kalmas Kabupaten Pangkep sebagai berikut:

\section{a. Faktor Pendukung \\ 1) Partisipasi masyarakat}

Partisipasi Masyarakat adalah keterlibatan seseorang atau pun suatu kelompok (masyarakat) secara aktif dalam berkontribusi dengan sukarela pada sebuah program pembangunan, seperti terlibat dalam hal perencanaan, pelaksanaan, monitoring dan juga sampai evaluasi. Faktor yang mendukung terlaksananya Proses pengelolaan ADD di Desa Sabaru adalah partisipasi masyarakat yang baik. Masyarakat cukup merespon setiap program penggunaan anggaran. Partispasi masyarakat dapat dilihat dari keinginan masyarakat dalam mengibahkan sebagian tanahnya kepada Pemerintah Desa. Hal tersebut sejalan

dengan pendapat Kepala Desa Sabaru, H.A. Sampewali mengatakan bahwa: "Faktor penunjang terlaksananya realisasi penggunaan ADD masyarakat cukup merespon, dan dalam pembuatan jalan tani masyarakat mengibahkan sebagian tanahnya" (Hasil Wawancara, 25 Juli 2019).

Berdasarkan hasil wawancara tersebut, masyarakat terlihat sangat antusias dalam membantu dan bekerjasama dalam pelaksanaan program Pemerintah Desa. Hal ini dapat memperlancar proses pengelolaan ADD yang akan dilaksanakan di Desa Sabaru. Salah satu program yang mendapat partisipasi masyarakat yakni program pembuatan jalan dimana masyarakat menghibahkan tanahnya untuk akses jalanan.

\section{2) Sarana dan Prasarana}

Sarana adalah segala sesuatu yang dapat dipakai sebagai alat dalam mencapai maksud atau tujuan. Sedangkan prasarana adalah segala sesuatu yang merupakan penunjang utama terselenggaranya suatu proses (usaha, pembangunan, proyek). Pada dasarnya, tujuan diadakannya perencanaan sarana dan prasarana adalah: a) untuk menghadiri terjadinya kesalahan dan kegagalan yang tidak diinginkan; dan b) untuk meningkatkan efektivitas dan efisiensi dalam pelaksanaanya. Salah rencana dan penentuan kebutuhan merupakan kekeliruan dalam menerapkan kebutuhan sarana dan prasarana yang kurang/tidak memandang kebutuhan ke depan dan kurang cermat dalam menganalisis kebutuhan sesuai dengan dana yang tersedia dan tingkat kepentingan.

Aparat Pemerintah Desa Sabaru terus berupaya menyediakan Sarana dan Prasarana untuk menunjang terlaksananya program yang akan di laksanakan, dengan diberikannya Motor Dinas untuk kepala Desa maka dapat memudahkan Kepala Desa dan Aparat Pemerintah Desa dalam melaksanakan tugasnya sebab tidak semua aparat Pemerintah Desa Sabaru memiliki kendaraan, Contohnya dalam membagikan undangan rapat kepada tokoh masyarakat dan melakukan survey sebelum menentukan program yang akan dilaksanakan seperti halnya Printer brother yang dapat meng fotocopy atau menggadakan dokumen sehingga dapat meminimalisir waktu yang terbuang. Hal ini sesuai yang diungkapkan oleh Perangkat Desa Sabaru bahwa: "Pemberian motor dinas sangat membantu kami dalam melaksankan tugas,apalagi sekarang ada printer yang bisa mengfotocopy jadi kita tidak perlu lagi jauhjauh untuk mengfotocopy”. (Hasil Wawancara 13 Juli 2019).

Berdasarkan realita tersebut, terlihat upaya Aparat Pemerintah Desa Sabaru dalam mendukung sarana dan Prasarana karena dapat menunjang terlaksananya program yang akan di laksanakan.

\section{b. Faktor Penghambat}

\section{1) Sumber Daya Manusia}

Sumber Daya Manusia merupakan faktor penting dalam proses pengelolaan Alokasi Dana Desa. Peran dan pentingnya Sumber Daya Manusia dalam Instansi Pemerintahan adalah bahwa segala potensi sumber daya yang dimiliki manusia yang dapat dimanfaatkan sebagai usaha untuk meraih keberhasilan dalam mencapai tujuan baik secara pribadi individu maupun di dalam instansi. Sumber daya tersebut meliputi tenaga dan kemampuan manusia (baik daya pikir serta daya fisiknya) benar-benar dapat dimanfaatkan secara terpadu dan secara optimal. Sumber Daya Manusia sebagai faktor pertama dan utama dalam proses pembangunan dan pencapaian tujuan Pemerintahan. Apabila di dalam Pemerintah Desa sudah memiliki modal besar, teknologi canggih, sumber daya alam melimpah namun tidak ada sumber daya manusia yang dapat mengelola dan memanfatkannya maka tidak akan mungkin dapat meraih keberhasilan. Oleh sebab itulah pentingnya peran sumber daya manusia dalam Pemerintah Desa itu sangat diperlukan sebagai unsur utama dan unsur pengendali keberhasilan Pemerintah Desa.

Sumber daya manusia dalam pengelolaan ADD meliputi Tim Pelaksana Kegiatan, Tim Pendamping Kecamatan dan BPMDK. Adapun tugas Tim pelaksana kegiatan tingkat Desa adalah menyusun rencana daftar kegiatan bersama pemerintah Desa, menyusun daftar rencana kegiatan beserta rencana anggaran biaya dan Tim Pelaksana Kegiatan bertanggungjawab kepada Kepala Desa sebagai Penanggungjawab dan Pemegang Kekuasaan Pengelolaan Keuangan Desa. Sementara itu tugas Tim Pendamping Kecamatan adalah memfasilitasi bimbingan teknis perencanaan kepada Tim Pelaksana Tingkat Desa, memberikan bimbingan dan asistensi penyusunan pengelolaan dan pemanfaatan Alokasi Dana Desa kepada Pelaksana Tingkat Desa dan melakukan fasilitasi pemecahan masalah berdasarkan pengaduan masyarakat serta pihak lainya dan melaporkan kepada Tim Fasilitasi Tingkat Kabupaten, dan tugas BPMDK adalah melakukan pembinaan terhadap Pemerintah Desa.

Dalam pengelolaan ADD, secara keseluruhan kinerja aparat Pemerintah Desa di Desa Sabaru Kecamatan Liukang Kalmas kurang baik. Hal ini terlihat dengan proses pengelolaan yang tidak sesuai jadwal. Terhambatnya proses pengelolaan ADD kebanyakan diakibatkan oleh kualitas sumber daya manusia sebagai penggerak. Aparat pemerintah Desa di Desa Sabaru rata-rata berpendidikan SMA/SMK Haltersebut menyebabkan kurangnyapengetahuan tentang pengelolaan ADD. 
Konteks untuk melaksanakan sejumlah keputusan Aparat Pemerintah Desa Sabaru dapat melaksanakanya, dengan adanya keterbatasan kualitas pendidikan Sumber Daya Manusia yang dimiliki oleh Aparat pemerintah Desa Sabaru menyebabkan terhambatnya proses pengelolaan ADD kebanyakan diakibatkan oleh kualitas Sumber Daya Manusia sebagai penggerak, Hal utama yang menjadi kendala dalam proses pengelolaan ADD disebabkan oleh Sekertaris Desa yang lama di alihkan ke kantor kecamatan dan di gantikan oleh Sekretaris Desa yang baru dengan pengetahuan dan pengalaman yang terbatas.

Aparat Pemerintah Desa sebagai penanggung jawab jalannya roda pemerintahan Desa sangat memiliki peran dalam menentukan keberhasilan pembangunan masyarakat. Latar belakang Pendidikan Sekretaris Desa Sabaru yang baru yakni Strata satu (S1), namun hal tersebut tidak menjadikan pengelolaan ADD terlaksana dengan baik di karenakan Sekretaris Desa Sabaru baru menjabat sekitar 6 bulan terakhir.

2) Peraturan tentang Petunjuk Teknis Alokasi Dana Desa Setiap Tahun Berubah.

Pengelolaan Alokasi Dana Desa telah diatur dalam Peraturan Bupati Pangkep Nomor 2 tentang Petunjuk Teknis Alokasi Dana Desa. Peraturan tentang pengelolaannya diatur berbeda setiap tahunnya. Fenomena tersebut menjadi kendala bagi Aparat Pemerintah Desa dalam melaksanakan pengelolaan Alokasi Dana Desa (ADD).

Merujuk pada hasil Wawancara, maka penulis membandingkan perbedaan Peraturan Bupati Pangkep nomor 2 tahun 2016 tentang petunjuk teknis Alokasi Dana Desa (ADD) dengan Peraturan Bupati Pangkep nomor 2 tahun 2017 tentang petunjuk teknis Alokasi Dana Desa yang membuat Aparat Pemerintah Desa Sabaru dilema dalam melaksanakan proses pengelolaan ADD. perbedaan peraturan Bupati nomor 2 tahun 2016 dengan Peraturan Bupati nomor 2 tahun 2017 terletak pada Bab V bagian kedua mekanisme pencairan pasal 10 bahwa rekomendasi pencairan dari BPMDK harus disertai dengan beberapa lampiran, untuk Laporan Berkala ( Tahap I ) disertai dengan lampiran :

a) Peraturan Desa Tentang Rencana Pembangunan Jangka Menengah Desa ( RPJMDesa)

b) Peraturan Desa tentang Rencana Kerja Pemerintah Desa (RKPDesa)

c) LPPD Akhir tahun pada tahun sebelumnya

d) LKPJ Akhir tahun pada tahun sebelumnya

e) Peraturan Desa Tentang APBDes tahun berjalan

f) Rencana Penggunaan Dana

g) Pertanggungjawaban Penggunaan Dana Tahap II Tahun Anggaran Sebelumnya.

h) SPTB bermaterai Rp.6.000,- tahap sebelumnya

i) Kwitansi bermaterai RP.6.000,-

j) Foto Copy Rekening Pemerintah Desa

k) Bebas temuan dari inspektorat Daerah Kabupaten Pangkep. Surat Permohonan Pencairan ADD Laporan Akhir (Tahap II) disertai dengan lampiran:

a) Rencana Penggunaan Dana

b) Surat Pernyataan Tanggungjawab belanja

c) Kwitansi bermaterai Rp. 6.000,-

d) Pertanggung Jawaban Tahap I (Pertama)

Sedangkan mekanisme pencairan dalam Peraturan Bupati nomor 2 tahun 2017 pasal 10 bahwa permohonan penyaluran/pencairan Alokasi Dana Desa (ADD) diajukan oleh Kepala Desa diketahui oleh Camat ditujukan kepada
Bupati Cq, Kepala BPKAD Kabupaten Pangkep, surat permohonan pencairan ADD di lampiri :

a) Rencana Penggunaan Dana (RPD) Tahap I/II

b) Surat pernyataan tanggungjawab belanja (tahap sebelumnya)

c) Pertangungjawaban Penggunaan ADD (setiap tahap)

d) Kwitansi bermaterai Rp. 6.000,-

e) Foto Copy rekening Pemerintah Desa

f) Bebas temuan tahun sebelumnya dari inspektorat Daerah Kabupaten Pangkep (untuk pencairan Tahap Pertama)

g) Rekomendasi Pencairan

Rekomendasi yang di maksud huruf (g) di keluarkan oleh Kepala Dinas PMD Kabupaten Pangkep setelah diadakan vertivikasi terhadap dokumen yang dipersyaratkan berikut :

a) Peraturan Desa tentang Rencana Pembangunan jangka menengah Desa (RPJMDesa).

b) Peraturan Desa tentang Rencana Kerja Pemerintah Desa (RKPDesa)

c) Peraturan Desa tentang Laporan Realisasi pelaksanaan APBDesa (tahun sebelumnya)

d) Peraturan Desa tentang Anggaran Pendapatan dan Belanja Desa (tahun sebelumnya)

e) Laporan Realisasi penggunaan Alokasi Dana Desa ( tahap sebelumnya )

f) Bebas temuan tahun sebelumnya dari inspektorat Daerah Kabupaten Pangkep.(untuk pencairan Tahap I)

g) Rencana Penggunaan Dana (RPD) tahap I/II

h) Laporan konsulidasi tahap I/II

Sedangkan dalam Peraturan Bupati nomor 2 tahun 2016 tentang petunjuk teknis ADD tidak terdapat peraturan mengenai penggunaan biaya pelaksanaan pemilihan kepala Desa, bagi Desa yang akan melaksanakan Pemilihan Kepala Desa dan mekanisme pencairan Dana tersebut dilampiri dokumen yang berbeda.

\section{3)Komunikasi}

Komunikasi proses penyampaian informasi (pesan, ide, gagasan) dari satu pihak kepada pihak lain. Komunikasi sangat penting dalam kehidupan manusia sebab komunikasi merupakan sebuah proses untuk menyampaikan maksud atau pesan yang menjadi tujuan kepada orang lain. Sehingga, jika manusia ingin menyampaikan apa yang ia maksudkan, ia harus berkomunikasi. begitu pula sebaliknya kita bisa memahami seseorang dengan melalui komunikasi. Namun realitas yang terjadi di Desa Sabaru komunikasi merupakan faktor penghambat dalam melaksanakan pengelolaan ADD, komunikasi masyarakat yang kurang mampu mengutarakan pendapat di depan umum sehingga Pemerintah Desa Sabaru mengalami kesulitan dalam menetukan program yang ingin di laksanakan. Dalam forum Musrenbang Desa Masyarakat cukup antusias untuk menghadiri MusrenbangDesa, namun berdasarkan hasil penelitian yang dilakukan penulis masyarakat kurang mampu mengeluarkan pendapat di depan umum

Berbicara di depan umum merupakan salah satu teknik atau seni berbicara yang harus dimiliki pembicara maupun peserta rapat untuk mampu menciptakan suansanarapat yang mempunyai feedback, sebab jika peserta rapat kebanyakan diam, maka forum MusrenbangDesa yang dilaksanakn oleh Aparat Pemerintah Desa Sabaru hanya berlangsung satu arah sehingga aparat pemerintah Desa Sabaru mempunyai kesulitan untuk mengetahui keinginan masyarakat. 


\section{KESIMPULAN}

Berdasarkan hasil penelitian yang telah dilakukan maka dapat disimpulkan sebagai berikut: Proses Pengelolaan ADD meliputi Perencanaan, Pelaksanaan, Penatausahaan, Pelaporan dan Pertanggungjawaban. Pengelolaan ADD yang dilakukan oleh Pemerintah Desa Sabaru Kecamatan Liukang Kalmas Kabupaten Pangkep telah mengikuti aturan petunjuk teknis yang telah diatur dalam peraturan perundang-undangan. $\mathrm{Na}-$ mun, dalam prosesnya masih belum optimal. Hal ini terlihat dari proses pelaporan dan pertanggungjawaban yang mengalami keterlambatan. Untuk proses Pelaporan Realisasi Penggunaan ADD belum sesuai dengan jadwal yang telah ditentukan sehingga menyebabkan keterlambatan pencairan Dana untuk tahapan berikutnya.; dan Faktor yang mempengaruhi pengelolaan Alokasi Dana Desa (ADD) meliputi faktor pendukung dan penghambat. Faktor pendukung yakni adanya Partisipasi masyarakat dalam hal mengibahkan tanahnya kepada Pemerintah Desa, Sarana dan Prasarana yang mema-dai. Sedangkan faktor penghambat yakni keterbatasan kualitas Sumber Daya Manusia Aparat pemerintah Desa di Desa Sabaru yang rata-rata berpendidikan SMA/SMK. Hal ini menyebabkan kurang nya pengetahuan tentang pengelolaan ADD dan Petunjuk teknis pengelolaan ADD yang setiap tahun berubah.Fenomena ini menyebabkan tim pelaksana kegiatan ADD mempunyai kesulitan dalam malaksanakan tugasnya dan Komunikasi masyarakat yang kurang mampu mengutarakan pendapat di depan umum.

\section{DAFTAR PUSTAKA}

Amiruddin, Askin dan Zainal. (2010). Pengantar Metode Penelitian Hukum.Jakarta: Raja Grafindo Persada.

Budiono. (2005). Kamus Lengkap Bahasa Indonesia. Surabaya: Karya Agung.

Fadli, Mohammad. (2013). Pembentukan Peraturan Desa Partisipatif. Malang: UBPrees.

Fauzan, Muhammad. 2006. Hukum Pemerintahan Daerah Kajian TentangHubungan Keuangan antara Pusat dan Daerah. Yogyakarta: UII Press.

Ndraha, Taliziduhu. (1991). Dimensi-Dimensi Pemerintahan Desa. Jakarta: BumiAksara.

Salim,H.S dan Erlis Septiana Nurbani. (2013) Penerapan Teori Hu-kum Pada Tesis dan Disertasi, Ediis Pertama, ctk Kesatu, Rajawali Press, Jakarta, Hal.375

Saparin, Sumber. (1979). Tata Pemerintahan dan Administrasi Pemerintahan Desa. Jakarta: Ghalia Indonesia.

Sujamto. (1987). Aspek-Aspek Pengawasan di Indonesia. Jakarta: Sinar Grafika.

Sunardjo, Unang.(1984). Pemerintahan Desa dan Kelurahan. Bandung: PenerbitTarsito.

Syafrudin, Ateng dan Suprin Na'a. (2010). Republik Desa: Pergulatan HukumTradisional dan Hukum Modern dalam Desai Otonomi Desa. Bandung: Penerbit PT. Alumni.

Tjandra, Riawan. (2006). Hukum Keuangan Negara. Jakarta: Grasindo.

Widjaja, H.A.W. 2003. Pemerintahan Desa/Marga.Jakarta: Penerbit PT.Raja Grafindo Persada..

Wolhof dalam Zein Zanibar. (2003). Otonomi Desa dengan Acuan Khusus pada Desa di Provinsi Sumatera Selatan. Jakarta: Disertasi UI.
Budiman, S. (2018) Isu-isu Strategis UU Desa.kkn.bunghatta. ac.id/downloadIsu\%20Strategis\%20UU\%20Desa.pdf.ht ml(online). [diakses 17 Juli 2018).

Hukumonline.com. [KPK] Komisi Pemberansatasan Korupsi. (2018). Siap Antisipasi Potensi Korupsi Dana Bantuan Desa.Edisi tanggal 11 Desember 2014 (online). [Diakses 17 Juli 2018]. 